\title{
Part B: Revisions to the COMFA outdoor thermal comfort model for application to subjects performing physical activity
}

\author{
Natasha A. Kenny • Jon S. Warland • \\ Robert D. Brown • Terry G. Gillespie
}

Received: 9 November 2008 /Revised: 18 February 2009 / Accepted: 25 March 2009/Published online: 26 April 2009

(C) ISB 2009

\begin{abstract}
The purpose of this paper is to improve the accuracy of the COMFA outdoor thermal comfort model for application to subjects performing physical activity. A sensitivity analysis was performed to identify conditions where the COMFA model produced erroneous estimates of the heat and moisture exchanges between the human body and the ambient environment, based on data from subjects performing moderate-to-vigorous physical activity. Errors occurred at high metabolic rates $\left(>400 \mathrm{~W} \mathrm{~m}^{-2}\right)$, high wind speeds $\left(>4 \mathrm{~m} \mathrm{~s}^{-1}\right)$ and warm air temperatures $\left(>28^{\circ} \mathrm{C}\right)$. Revisions to the clothing resistance $\left(r_{\mathrm{c}}\right)$, clothing vapour resistance $\left(r_{\mathrm{cv}}\right)$, skin tissue resistance $\left(r_{\mathrm{t}}\right)$, and skin temperature $\left(T_{\mathrm{sk}}\right)$ equations were proposed. The revised assessment revealed that subjects had a wide range of thermal acceptability $\left(\mathrm{B}=-20 \mathrm{~W} \mathrm{~m}^{-2}\right.$ to $\left.+150 \mathrm{~W} \mathrm{~m}^{-2}\right)$, which was offset to the warm-end of the comfort scale. The revised model (COMFA*) performed well, predicting the actual thermal sensation of subjects in approximately $70 \%$ of cases. This study effectively integrated current empirical research related the effect of wind and activity on the clothing microclimate to improve the application of an
\end{abstract}

\footnotetext{
N. A. Kenny $(\bowtie)$

Teaching Support Services, University of Guelph,

Day Hall,

Guelph, NIG 2W1 ON, Canada

e-mail: nkenny@uoguelph.ca
}

J. S. Warland • T. G. Gillespie

Department of Land Resource Science, University of Guelph,

Guelph, ON, Canada

R. D. Brown

School of Environmental Design and Rural Development,

University of Guelph,

Guelph, ON, Canada outdoor thermal comfort model for subjects performing physical activity.

Keywords Outdoor thermal comfort · Physical activity .

Clothing resistance $\cdot$ Skin tissue resistance $\cdot$ Skin temperature

\section{List of symbols and abbreviations}

ATS Actual thermal sensation

$B \quad$ COMFA budget value $\left(\mathrm{W} \mathrm{m}^{-2}\right)$

$C \quad$ Convective heat losses from a person $\left(\mathrm{W} \mathrm{m}^{-2}\right)$

CRT Cylindrical radiation thermometer

E Evaporative heat losses from a person $\left(\mathrm{W} \mathrm{m}^{-2}\right)$

$L \quad$ Longwave radiation emitted from a person (W

$\mathrm{m}^{-2}$ )

$L_{v} \quad$ Latent heat of vaporisation $\left(\mathrm{J} \mathrm{kg}^{-1}\right)$

$M \quad$ Metabolic heat generated by a person $\left(\mathrm{W} \mathrm{m}^{-2}\right)$

$M_{a} \quad$ Metabolic activity $\operatorname{rate}\left(\mathrm{W} \mathrm{m}^{-2}\right)$

$P \quad$ Clothing permeability $\left(1 \mathrm{~m}^{2} \mathrm{~s}^{-1}\right)$

$P_{a} \quad$ Atmospheric pressure $(\mathrm{kPa})$

$\mathrm{Pr} \quad$ Prandtl number

RH Relative humidity (\%)

$r_{a} \quad$ Boundary air layer resistance $\left(\mathrm{s} \mathrm{m}^{-1}\right)$

$r_{a v} \quad$ Boundary air layer resistance to water vapour $\left(\mathrm{s} \mathrm{m}^{-1}\right)$

$r_{c} \quad$ Clothing resistance $\left(\mathrm{s} \mathrm{m}^{-1}\right)$

$r_{c o} \& \quad$ Clothing resistance $\left(\mathrm{s} \mathrm{m}^{-1}\right)$ (static no reduction

$r_{c(s t) \quad \text { factor) }}$

$r_{c v} \quad$ Clothing vapour resistance $\left(\mathrm{s} \mathrm{m}^{-1}\right)$

$r_{c v o} \& \quad$ Clothing vapour resistance (static no reduction

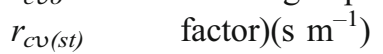

$r_{t} \quad$ Body tissue resistance $\left(\mathrm{s} \mathrm{m}^{-1}\right)$

PTS Predicted thermal sensation

$R_{R T} \quad$ Radiation absorbed calculated using a CRT $\left(\mathrm{W} \mathrm{m}^{-2}\right.$ ) 


$\begin{array}{ll}T_{a} & \text { Air temperature }\left({ }^{\circ} \mathrm{C}\right) \\ T_{c} & \text { Core temperature }\left({ }^{\circ} \mathrm{C}\right) \\ V & \text { Air velocity }\left(\mathrm{m} \mathrm{s}^{-1}\right) \\ v & \text { Kinematic viscosity of air }\left(\sim 1.5 \times 10^{-5} \mathrm{~m}^{2} \mathrm{~s}^{-1}\right) \\ v_{a c} & \text { Activity velocity }\left(\mathrm{m} \mathrm{s}^{-1}\right) \\ v_{r} & \text { Relative air velocity }\left(\mathrm{m} \mathrm{s}^{-1}\right) \\ z & \text { Height }(\mathrm{m}) \\ \rho C_{p} & \text { Volumetric heat capacity of air }\left(\sim 1,200 \mathrm{~J} \mathrm{~m}^{-3}\right. \\ & \left.\mathrm{K}^{-4}\right)\end{array}$

\section{Introduction}

Part A of this project, which was presented as a previous paper in this issue provided a comprehensive assessment of the performance of the COMFA outdoor thermal comfort model on subjects performing moderate-to-vigorous physical activity. The results suggested that the COMFA model performed well in most cases. However, there were discrepancies between the actual thermal sensation (ATS) and predicted thermal sensation (PTS) votes and the model did not perform as well as the original assessment of the COMFA model on sedentary users (Brown and Gillespie 1986). In a small number of cases $(\sim 6 \%)$ the model substantially over- or under-estimated the thermal sensation of subjects during the field tests, suggesting that, under specific conditions, there may be errors associated with the equations used to calculate the COMFA budget.

The COMFA heat balance represents a way of integrating the complex interactions that occur between the human body and the ambient thermal environment, and perceptions of thermal sensation (as suggested by the correlation analysis in Part A). As the model was originally developed for users performing activity at low metabolic rates, it is important to further assess its application to users performing higher levels of activity. Although many authors have attributed discrepancies between ATS and PTS votes within outdoor environments to psychological factors, such as expectancy, thermal history, environmental stimulation, time of exposure and choice (Nikolopoulou et al. 2001; Nikolopoulou and Steemers 2003; Nikolopoulou and Lykoudis 2006; Spagnolo and de Dear 2003; Thorsson et al. 2004, 2007), research has suggested also that outdoor thermal comfort models must be improved to more accurately address individual factors such as clothing properties and metabolic heat production (Havenith et al. 2002). Even in their original assessment of the COMFA model, Brown and Gillespie (1986) noted that additional research to improve the quantification of clothing vapour resistance for application within the model was warranted.

Clothing insulation and vapour resistance are important parameters within the COMFA model, and greatly affect the heat and moisture transfer between the body and the surrounding environment. Many thermal comfort models require the input of a basic or 'intrinsic' thermal insulation value. Values for intrinsic insulation can be obtained from sources with comprehensive tables of insulation values for a range of clothing ensembles (e.g. ISO9920 2007; McCullough et al. 1989). The intrinsic insulation values often are representative of static, standing conditions and do not take into account the effects of body motion or air movement on clothing insulation. Research has found that heat transfer through clothing is affected significantly by body and air movements, and that the intrinsic insulation values often provide an overestimate of the actual insulation provided by clothing in dynamic conditions (Nielsen et al. 1985; Lotens and Havenith 1991; Holmer et al. 1999; Havenith et al. 1990a, 1990b, 2002). This is especially important in the evaluation of outdoor thermal comfort, where the effects of activity and wind speed must be taken into consideration to accurately account for the effect of clothing on heat and vapour transfer.

Since the original development of the COMFA model, many studies have focussed on the effect of body and air movement on clothing insulation and vapour resistance (Havenith et al. 1990a, 1990b; Lotens and Havenith 1991; Lotens and Wammes 1993; Havenith et al. 1999; Holmer et al. 1999; Ghali et al. 2002; Bouskill et al. 2002; Fukazawa et al. 2004; Havenith and Nilsson 2004). Research has concluded that activity and wind can reduce clothing insulation by more than $50 \%$, and vapour resistance by over $80 \%$, in comparison to the static resistance values (Havenith et al. 2002). Various clothing insulation and vapour resistance correction factors have been proposed (Bouskill et al. 2002; Havenith et al. 2002; Holmer et al. 1999; Parsons et al. 1999), although many are limited to wind speeds less than $3.5 \mathrm{~m} \mathrm{~s}^{-1}$ and activity speeds less than $1.2 \mathrm{~m} \mathrm{~s}^{-1}$.

The COMFA model as presented does not consider the combined effects of wind and activity speed on heat and moisture transfer exchanges between the body and the ambient environment. Although the COMFA model provides a simplified reduction equation for clothing resistance $\left(r_{\mathrm{c}}\right)$, it is important to integrate more accurately recent research on clothing insulation and vapour resistance.

The purpose of this paper is to improve the accuracy of the model for application on subjects performing moderatevigorous physical activity and to integrate recent research pertaining to the effect of activity and wind speed on clothing insulation and vapour resistance into the COMFA model. This goal will be accomplished through the following objectives:

- to further assess the discrepancy between ATS and PTS votes presented in Part A of this project, by identifying the conditions under which the model substantially 
under- or over-estimated the heat and moisture exchange between the human body and the ambient environment;

- to perform a sensitivity analysis to identify how changes to each of the COMFA model inputs [i.e. air temperature $\left(T_{\mathrm{a}}\right)$, cylindrical radiation thermometer (CRT) temperature $\left(T_{r t}\right)$, relative humidity $(\mathrm{RH})$, clothing insulation $\left(r_{c o}\right)$ and permeability $(P)$, wind speed $(V)$ and metabolic activity $\left(M_{a}\right)$ ] affect the predicted budget values;

- to propose revisions to the COMFA outdoor thermal comfort model and re-analyse the data presented in Part A.

\section{Methods}

Assessing the outlier and extreme values

The COMFA model substantially over- or under-estimated PTS values in $6 \%$ of the cases presented in Part A. A summary of the conditions in which the COMFA model produced these outlier and extreme values is presented in Table 1. The corresponding model outputs and ATS votes are presented in Table 2. The majority of the extreme and outlier values (91\%) were calculated under high wind speeds (3.0-4.9 $\mathrm{m} \mathrm{s}^{-1}$ ), and approximately $70 \%$ of the extreme and outlier values were predicted on 13 July 2007 , when the average $1.5 \mathrm{~m}$ wind speed measured almost $5.0 \mathrm{~m}$ $\mathrm{s}^{-1}$. On this day, the corresponding PTS ranged from -3 (cold) to -1 (slightly cool), while the actual thermal sensation ratings of the subjects tested ranged from 0 (neutral) to +2 (warm). High wind speeds did not consistently result in underestimates of the thermal sensation of the subjects. In three of the high wind speed cases (15 July 2007 and 18 September 2007) the PTS of the model was +2 (warm) and it overestimated the 0 (neutral) ATS ratings.
Sensitivity analysis

The COMFA budget is calculated based upon a complex interaction of meteorological data (air temperature, radiation, wind speed, relative humidity) and participant data (metabolic activity, clothing resistance and permeability) inputs. As it is difficult to clearly discern the errors in the model from the above noted data presented in Tables 1 and 2, we performed a sensitivity analysis. This analysis will determine how changes to each of the COMFA model inputs (i.e. air temperature, CRT temperature, relative humidity, clothing insulation and permeability, wind velocity and metabolic activity) affect the model budget outputs, and clearly identify obvious errors in the model. Because most of the errors occurred on 13 July 2007, the average conditions from this date (see Table 1) will be used as a starting point for the analysis. Each of the input variables will be changed in accordance with the following ranges and increments:

- $T_{\mathrm{a}}=17.0-25.0^{\circ} \mathrm{C}$ at increments of $0.2^{\circ} \mathrm{C}$ [assuming a constant radiation absorbed $(R)$ value of $\left.380 \mathrm{~W} \mathrm{~m}^{-2}\right]$;

- $T_{\mathrm{rt}}=18.0-25.0^{\circ} \mathrm{C}$ at increments of $0.2^{\circ} \mathrm{C}$;

- $R H=20.0-100 \%$ at increments of $5 \%$;

- $V=1.0-7 \mathrm{~m} \mathrm{~s}^{-1}$ at increments of $0.1 \mathrm{~m} \mathrm{~s}^{-1}$;

- $M_{\mathrm{a}}=50-1,000 \mathrm{~W} \mathrm{~m}^{-2}$ at increments of $10 \mathrm{~W} \mathrm{~m}^{-2}$;

- $r_{\mathrm{co}}=50-300 \mathrm{~s} \mathrm{~m}^{-1}$ at increments of $10 \mathrm{~s} \mathrm{~m}^{-1}$; and

- $P=50-1,5001 \mathrm{~m}^{2} \mathrm{~s}^{-1}$ at increments of $15\left(1 \mathrm{~m}^{2} \mathrm{~s}^{-1}\right)$.

The analysis performed to assess the sensitivity of COMFA budgets to changes in air temperature, relative humidity, CRT temperature and clothing permeability did not reveal any unreasonable results. Air temperature, CRT temperature and relative humidity all displayed a positive, linear relationship with the budget values. With the $R$ value held constant at $380 \mathrm{~W} \mathrm{~m}^{-2}$, a $0.2^{\circ} \mathrm{C}$ increase in air temperature resulted in a $6 \mathrm{~W} \mathrm{~m}^{-2}$ increase in the COMFA budget. The budget was particularly sensitive to changes in CRT temperature, where an increase in $0.2^{\circ} \mathrm{C}$ resulted in a $12 \mathrm{~W} \mathrm{~m}^{-2}$ increase in the

Table 1 Summary of the mean meteorological and participant data for the outlier and extreme COMFA budget values presented in Part A. $T_{a}$ Air temperature, $T_{r t}$ cylindrical radiation thermometer (CRT)

temperature, $R H$ relative humidity, $V$ wind velocity, $v_{a}$ activity velocity, $M_{a}$ metabolic activity rate, $r_{c o}$ clothing resistance, $P$ clothing permeability

\begin{tabular}{llllllllll}
\hline Date & $N$ & $T_{a}\left({ }^{\circ} \mathrm{C}\right)$ & $T_{r t}\left({ }^{\circ} \mathrm{C}\right)$ & $R H(\%)$ & $V\left(\mathrm{~m} \mathrm{~s}^{-1}\right)$ & $v_{a}\left(\mathrm{~m} \mathrm{~s}^{-1}\right)$ & $M_{a}\left(\mathrm{~W} \mathrm{~m} \mathrm{~m}^{-2}\right)$ & $r_{c o}\left(\mathrm{~s} \mathrm{~m}^{-1}\right)^{\mathrm{a}}$ & $P\left(\mathrm{~lm}^{2} \mathrm{~s}^{-1}\right)$ \\
\hline 13 July 2007 & 15 & 18.0 & 19.3 & 52.2 & 4.9 & 2.8 & 565 & 76 & 1,479 \\
15 July 2007 & 2 & 21.2 & 23.9 & 43.4 & 4.2 & 5.9 & 465 & 87 & 724 \\
30 July 2007 & 1 & 23.7 & 27.9 & 50.7 & 1.7 & 3.1 & 670 & 76 & 1,479 \\
19 August 2007 & 1 & 19.0 & 22.0 & 45.6 & 1.8 & 5.0 & 349 & 95 & 724 \\
30 August 2007 & 1 & 17.2 & 19.3 & 75.3 & 3.7 & 0.0 & 116 & 95 \\
18 September 2007 & 2 & 22.3 & 25.0 & 45.1 & 3.0 & 5.0 & 349 & 95 & 893
\end{tabular}

${ }^{\text {a }}$ The clothing resistance expression $m^{2}{ }^{\circ} C W^{-1}$ is converted to $\mathrm{s} \mathrm{m}^{-1}$ by multiplying the clothing insulation values $\left(I_{c l}\right)$ by $\rho C p$, where $\rho$ is the density of air $\left(\mathrm{kg} \mathrm{m}^{-3}\right)$ and $C_{p}$ is the specific heat of air $\left(\mathrm{J} \mathrm{kg}^{-1}{ }^{\circ} \mathrm{C}^{-1}\right)$ 
Table 2 Summary of the output data and the corresponding subjective participant actual thermal sensation (ATS) votes for the outlier and extreme COMFA budget values presented in Part A. C
Convective heat losses, $M$ metabolic heat production, $E$ evaporative heat losses, $L$ longwave radiation emitted, $R_{R T}$ radiation absorbed based on CRT measurements, $B$ Budget

\begin{tabular}{llllllcc}
\hline Date & $C\left(\mathrm{~W} \mathrm{~m}^{-2}\right)$ & $M\left(\mathrm{~W} \mathrm{~m}^{-2}\right)$ & $E\left(\mathrm{~W} \mathrm{~m}^{-2}\right)$ & $L\left(\mathrm{Wm}^{-2}\right)$ & $R_{R T}\left(\mathrm{~W} \mathrm{~m}^{-2}\right)$ & $B\left(\mathrm{~W} \mathrm{~m}^{-2}\right)$ & $A T S^{\mathrm{a}}$ \\
\hline 13 July 2007 & $419-580$ & $466-521$ & $182-207$ & $279-405$ & $367-420$ & $-256-87$ & 0 to +2 \\
15 July 2007 & $177-219$ & 418 & 160 & $313-314$ & $295-436$ & $177-220$ \\
30 July 2007 & 152 & 609 & 247 & 386 & 491 & 314 \\
19 August 2007 & 92 & 312 & 115 & 304 & 380 & 0 \\
30 August 2007 & 216 & 104 & 28 & 311 & 373 & 0 \\
18 September 2007 & 104 & 314 & 115 & 312 & 411 & -76.9 & 0 \\
\end{tabular}

${ }^{a}$ Rated on a 7-point scale: -3 (cold), -2 (cool), -1 (slightly cool), 0 (neutral), +1 (slightly warm), +2 (warm), +3 (hot)

COMFA budget. Relative humidity had less of an overall impact on the budget values; each $5 \%$ increase in $\mathrm{RH}$ changed the budget value by only $1 \mathrm{~W} \mathrm{~m}^{-2}$. Clothing permeability was negatively related to the COMFA budget values. A $P$ increase of $25.5\left(1 \mathrm{~m}^{2} \mathrm{~s}^{-1}\right)$ decreased the budget by $7 \mathrm{~W} \mathrm{~m}^{-2}$.

Figure 1 displays the results of the sensitivity analysis for clothing insulation. Given the conditions on 13 July 2007, an increase in clothing insulation actually decreased the COMFA budget values, which suggests an error in the budget equations associated with clothing insulation at high wind speeds. With a reduced wind speed $\left(3.8 \mathrm{~m} \mathrm{~s}^{-1}\right)$, the model more reasonably predicts an increase of $3 \mathrm{~W} \mathrm{~m}^{-2}$ in the COMFA budget, with a corresponding increase in clothing insulation of $10 \mathrm{~s} \mathrm{~m}^{-1}$ (Fig. 1b).

Errors were also clearly revealed by the sensitivity analysis for metabolic activity, which showed an exponential decrease in the COMFA budget beyond a $M_{a}$ of approximately $400 \mathrm{~W} \mathrm{~m}^{-2}$, and for wind speed, which displayed an exponential decrease in the budget values beyond $4 \mathrm{~m} \mathrm{~s}^{-1}$ (Fig. 2).

There are three resistance values associated with the COMFA budget calculations: skin tissue resistance $\left(r_{t}\right)$, clothing resistance $\left(r_{\mathrm{c}}\right)$ and boundary air resistance $\left(r_{\mathrm{a}}\right)$. Figures 3 and 4 show a sensitivity analysis of tissue resistance to changes in metabolic activity, and the clothing and boundary air layer resistances to changes in wind speed. The $r_{\mathrm{a}}$ values, predicted based on engineering heat transfer theory for cylinders (Kreith and Black 1980), decrease rapidly from 0 to $1 \mathrm{~m} \mathrm{~s}^{-1}$, and continue to decrease moderately to values of just below $50 \mathrm{~s} \mathrm{~m}^{-1}$ at wind speeds of $7 \mathrm{~m} \mathrm{~s}^{-1}$. These values appear to be consistent with research on the aerodynamic resistance of air presented by Oke (1987) and Monteith and Unsworth (1990), and empirical research into the effects of activity and wind speed on the boundary layer air resistance within the "clothing microclimate' presented by Lotens and Havenith (1991).

Errors are evident with the negative resistance values predicted for $r_{\mathrm{t}}$ beyond a metabolic activity rate of $650 \mathrm{~W}$

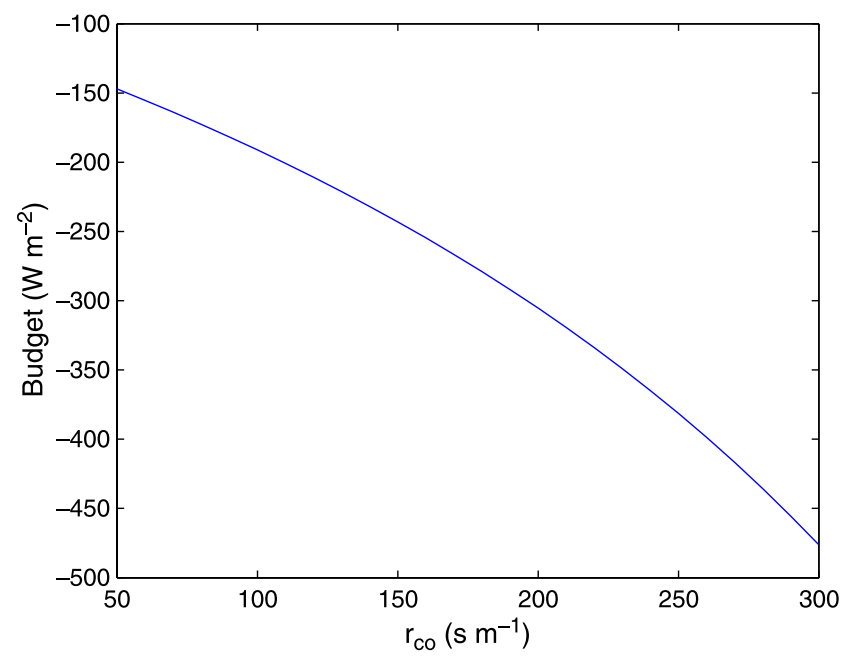

(a)

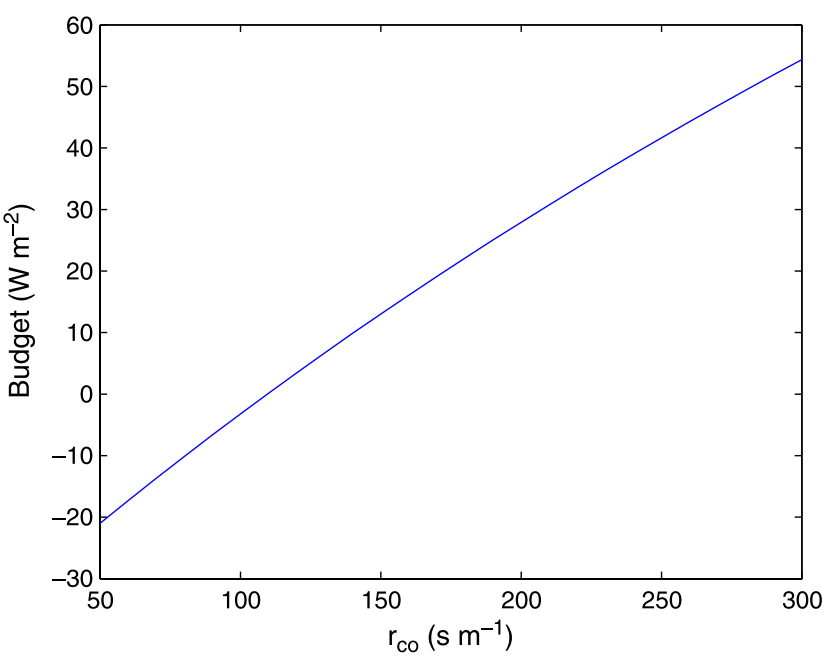

(b)

Fig. 1 Sensitivity of COMFA budget values to changes in clothing insulation given a the average conditions on 13 July 2007 (wind speed= $4.9 \mathrm{~m} \mathrm{~s}^{-1}$ ), and $\mathbf{b}$ a reduced wind speed of $3.8 \mathrm{~m} \mathrm{~s}^{-1}$ 


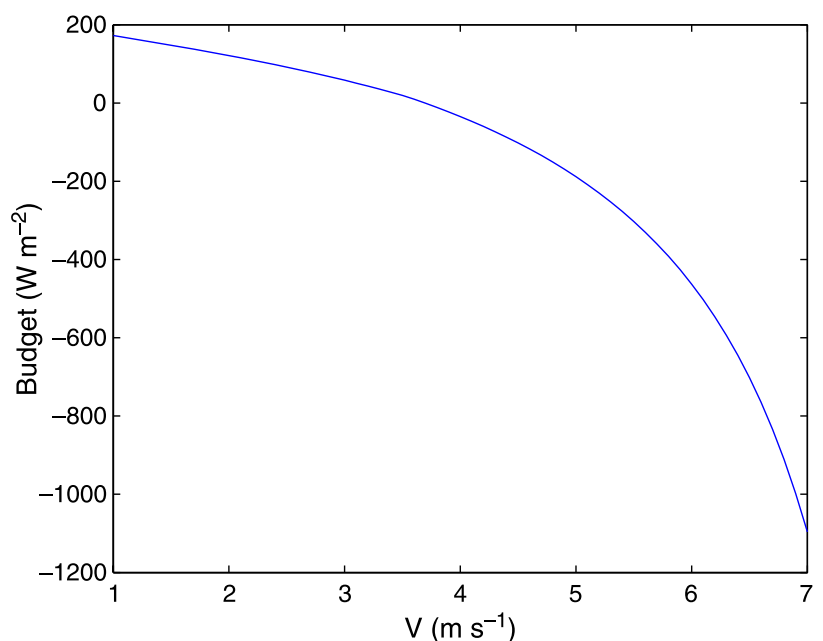

(a)

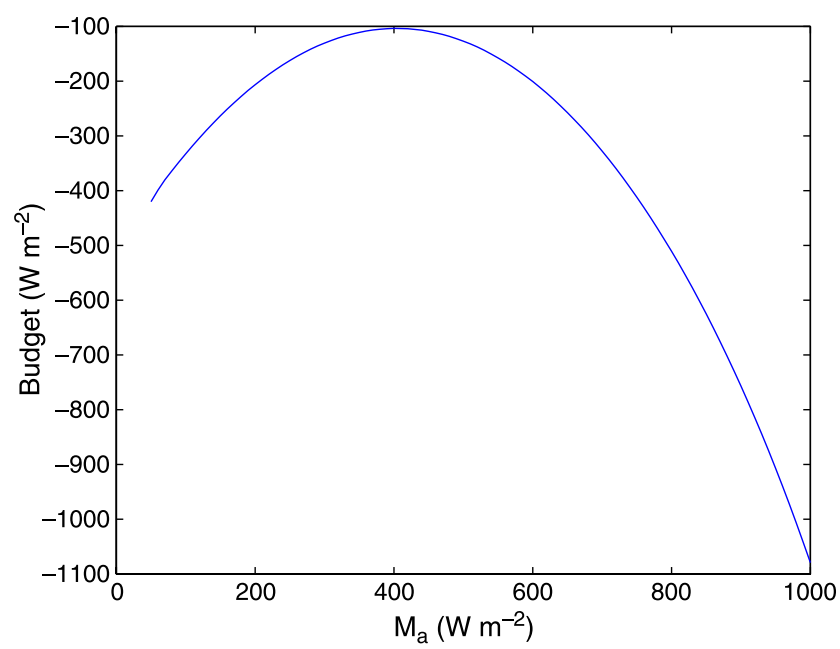

(b)

Fig. 2 Sensitivity of COMFA budget values to changes in a wind speed, and $\mathbf{b}$ metabolic activity given the average conditions on 13 July 2007

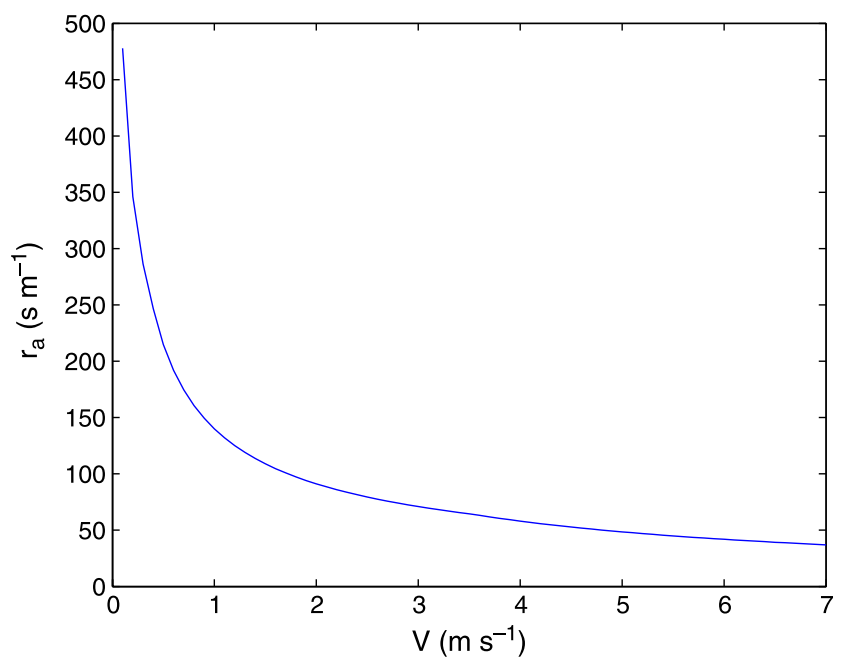

Fig. 3 Sensitivity of boundary air layer resistances to changes in wind speed

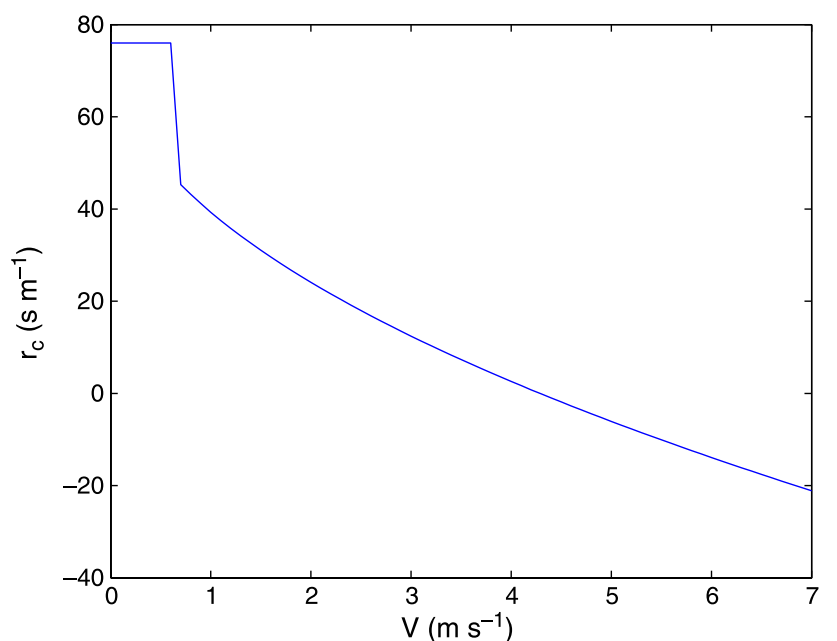

(a)

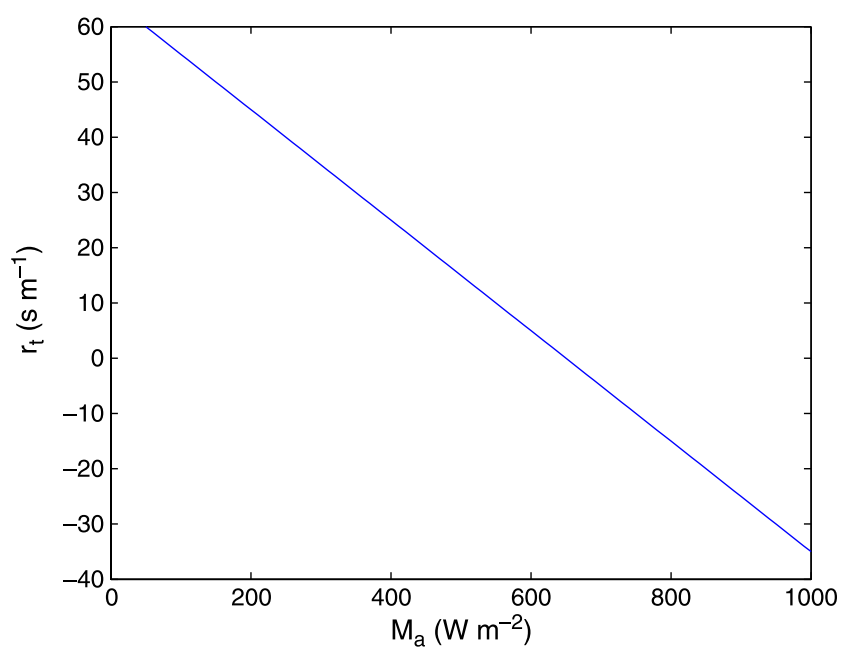

(b)

Fig. 4 Sensitivity of clothing resistance $\left(r_{\mathrm{co}}=76 \mathrm{~s} \mathrm{~m}^{-1}\right.$ and $P=1,4791$ $\mathrm{m}^{2} \mathrm{~s}^{-1}$ ) to a changes in wind speed, and b sensitivity of tissue resistance values to changes in metabolic activity

$\mathrm{m}^{-2}$, and for $r_{\mathrm{c}}$ beyond wind speeds of approximately $4 \mathrm{~m}$ $\mathrm{s}^{-1}$, indicating the need for revisions to the COMFA tissue resistance and clothing resistance equations for application at high metabolic rates and wind speeds (Fig. 4). Brown and Gillespie (1986) developed the COMFA tissue resistance $\left(r_{\mathrm{t}}\right)$ equation based on data presented by Fanger (1972), and our results clearly suggest that its application is limited to relatively low metabolic rates. Likewise, the clothing resistance $\left(r_{\mathrm{c}}\right)$ equation presented by Brown and Gillespie (1986) and Campbell (1977) is limited to relatively low wind speeds.

Skin tissue resistance and activity

Skin tissue resistance $\left(r_{\mathrm{t}}\right)$ is highly dependent upon the body's response to heat and cold through vasodilation and vasoconstriction. Kerslake (1972) proposed the linear 
relationship between sweat rate $(S)$ and peripheral tissue conductance $(C)$ to heat flow $\left(\mathrm{W} \mathrm{m}^{-2}{ }^{\circ} \mathrm{C}\right)$ as:

$S=7.5(C-15)$

He states, "In view of the general similarity between sudomotor [nerve control of sweat glands] and cutaneous vasomotor [constriction and dilation of blood vessels] responses to changes in metabolic rate or environment, it is attractive to suppose that the efferent systems are linked so that sweat production and vasodilation proceed hand in hand (Kerslake 1972, p 168)." Based on Eq. 1, as conductance is equal to resistance ${ }^{-1}, r_{\mathrm{t}}\left(\mathrm{s} \mathrm{m}^{-1}\right)$ in relation to the COMFA model becomes:

$r_{t}=\frac{\rho C p}{0.13 E_{s}+15}$

where $E_{\mathrm{s}}$ is the evaporative heat loss through sweat $\left(\mathrm{W} \mathrm{m}^{-2}\right)$, $\rho$ is the density of air $\left(\mathrm{kg} \mathrm{m}^{-3}\right)$ and $C_{\mathrm{p}}$ is the specific heat of air $\left(\mathrm{J} \mathrm{kg}^{-1}{ }^{\circ} \mathrm{C}^{-1}\right)$. Figure 5 shows the sensitivity of this tissue resistance equation (Eq. 2) to change in metabolic activity. In contrast to the errors evident in Fig. 4b, the values produced in Fig. 5 appear to be consistent with those presented by Monteith and Unsworth (1990) and Campbell and Norman (1998), who suggest that the resistance of vasoconstricted tissue is $90-120 \mathrm{~s} \mathrm{~m}^{-1}$, while that of vasodilated tissue is $15-30 \mathrm{~s} \mathrm{~m}^{-1}$.

\section{Wind speed}

When considering the heat transfer between the body and the ambient environment, it is important to consider the relative air movement $\left(v_{r}\right)$ between the body and the environment as determined by both the wind and activity speed. As the COMFA model was originally developed for

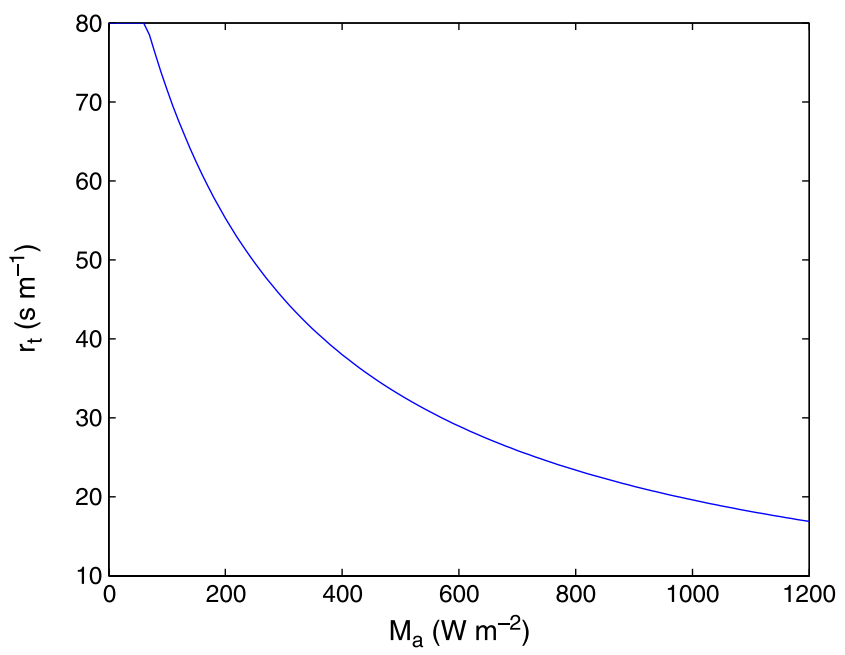

Fig. 5 Sensitivity of revised tissue resistance equation to changes in metabolic activity at air temperature $\left(T_{\mathrm{a}}\right)=22^{\circ} \mathrm{C}$ and relative humidity $(\mathrm{RH})=50 \%$ application under sedentary conditions, it does not consider the combined effects of wind and activity speed on the heat and moisture transfer from the human body to the environment. In outdoor environments, wind direction and a person's movement in relation to the wind is not always constant, and calculation of a representative value for $v_{r}$ becomes difficult.

A simple means of calculating an effective air velocity is given by Holmer et al. (1999) as the geometric mean:

$v_{r}=\sqrt{v_{w}^{2}+v_{a}^{2}}$

where $v_{w}$ is the wind speed $\left(\mathrm{m} \mathrm{s}^{-1}\right)$ and $v_{a}$ is the activity speed $\left(\mathrm{m} \mathrm{s}^{-1}\right)$.

Developing clothing insulation and vapour resistance correction factors for application in the COMFA model

The ability of a clothing ensemble to allow the evaporation of sweat from the skin to the environment is an important factor in determining thermal comfort when ambient temperatures, humidity, and metabolic activity levels are high. Under these conditions, the human body becomes more dependent on evaporative heat loss for maintenance of a near energy balance. Although the body possesses high capacity for evaporative heat loss to the environment through sweating, this process is attenuated by the fact that clothing creates an additional resistance to vapour transport (Havenith et al. 1999). The total evaporative resistance of a clothing ensemble $\left(R_{\text {ecl }}\right)$ is commonly expressed in the unit $\mathrm{m}^{2} \mathrm{kPa} \mathrm{W}^{-1}$. The following equation is used to convert the unit $\mathrm{m}^{2} \mathrm{kPa} \mathrm{W}^{-1}$ to the standard micrometeorological unit for evaporative resistance $\left(r_{v}\right)$ in units $\mathrm{s} \mathrm{m}^{-1}$ :

$r_{v}=\frac{0.622 L_{v} \rho R_{e c l}}{P_{a}-e_{a}}$

where $L_{v}$ is the latent heat of vaporisation $\left(\mathrm{J} \mathrm{kg}^{-1}\right), e_{\mathrm{a}}$ is the ambient vapour pressure $(\mathrm{kPa}), \rho$ is the air density $\left(\mathrm{kg} \mathrm{m}^{-3}\right)$ and $P_{\mathrm{a}}$ is the atmospheric pressure $(\mathrm{kPa})$.

Clothing insulation and vapour resistance are important parameters within the COMFA model and greatly affect the heat and moisture transfer between the body and the surrounding environment. Corrective equations that predict the dynamic effects of wind and activity on clothing thermal insulation and vapour resistance have been provided in various sources (ISO9920 2007; Havenith and Nilsson 2004; Havenith et al. 1999, 2002; Holmer et al. 1999; Bouskill et al. 2002; Parsons et al. 1999). However, the corrective equations are often limited to wind speeds less than $3.5 \mathrm{~m} \mathrm{~s}^{-1}$ and activity speeds less than $1.3 \mathrm{~m} \mathrm{~s}^{-1}$. As the conditions assessed in this study often exceeded these ranges, alternative correction factors are required for 
integration into the COMFA model. These same researchers suggest a rapid decrease in clothing dry heat and vapour resistance with air velocity, which asymptotes at high air velocity values, so it is proposed that an exponential decay equation analogous to a timeconstant equation for instrument response be applied.

Based on data presented by Havenith et al. (1990b) and Nielsen et al. (1985) the maximum clothing resistance correction factor was estimated as 0.63 (a maximum reduction of $37 \%$ of the static clothing insulation value). The maximum clothing vapour resistance correction factor $r_{c v}$ was estimated as 0.20 (a maximum reduction of $80 \%$ of the static clothing vapour resistance value) based on the data presented by Havenith et al. (1990a). For application in the COMFA model, the revised clothing resistance $\left(\mathrm{s} \mathrm{m}^{-1}\right)$ becomes:

$r_{c}=r_{c o}\left(-0.37\left(1-\exp ^{\frac{-v_{c}}{0.72}}\right)+1\right)$

where $r_{c o}$ is the static clothing resistance $\left(\mathrm{s} \mathrm{m}^{-1}\right)$ and $v_{a c}$ is the activity speed. $v_{a c}$ is applied to the dry clothing resistance value based on research presented by Havenith et al. (1990b) and Nielsen et al. (1985), who found that wind alone does not significantly reduce clothing insulation, but even at relatively low activity speeds the pumping effect caused by movement greatly reduces clothing resistance.

Clothing vapour resistance $\left(\mathrm{s} \mathrm{m}^{-1}\right)$ is represented as:

$r_{c v}=r_{c v o}\left(-0.80\left(1-\exp ^{\frac{-v_{r}}{1.095}}\right)+1\right)$

where $r_{c v o}$ is the static clothing vapour resistance and $v_{r}$ is the relative wind velocity calculated based upon both wind and activity speed. $v_{r}$ was applied to clothing vapour resistance as both Lotens and Wammes (1993) and Havenith et al. (1990a) found that both wind and activity speed substantially impact clothing vapour resistance. Static clothing insulation $\left(r_{c v o}\right)$ values can be obtained from ISO9920 (2007).

\section{Skin temperature}

Similar to Fanger's (1972) approach to estimating mean skin temperature, the COMFA model presented in Part A of this issue assumes a decrease in skin temperature with a corresponding increase in metabolic activity. However, Mairiaux et al. (1987) found that the single best predictor of mean skin temperature is air temperature and that the two variables are positively correlated. Further, they suggest that although metabolic activity greatly contributes to core body temperature, it has only a slight influence on mean skin temperature.

Laboratory research on athletes performing moderate-tovigorous physical activity has found that mean skin temperature values range from approximately $26^{\circ} \mathrm{C}$ to $30^{\circ} \mathrm{C}$ in cool environments $\left(T_{\mathrm{a}}=8-10^{\circ} \mathrm{C}\right), 31-33^{\circ} \mathrm{C}$ in neutral environments $\left(T_{\mathrm{a}}=20-24^{\circ} \mathrm{C}\right)$, and $33-37^{\circ} \mathrm{C}$ in hot environments $\left(T_{\mathrm{a}}=30-40^{\circ} \mathrm{C}\right)$ ( Maw et al. 1993; Sparks et al. 2005). The estimated $T_{s k}$ at various air temperatures and metabolic rates using the $T_{s k}$ equation in Part $\mathrm{A}$ are presented in Fig. 6. The apparent link between $T_{a}$ and $T_{s k}$ is clearly not evident in these results, and the predicted $T_{s k}$ values are inconsistent with data presented by Maw et al. (1993) and Sparks et al. (2005).

The original COMFA equation presented by Brown and Gillespie (1986), where:

$T_{s k}=\left(\frac{T_{c}-T_{a}}{r_{t}+r_{c}+r_{a}}\right)\left(r_{a}+r_{c}\right)+T_{a}$

appears to produce $T_{s k}$ values that are more consistent with research conducted by Mairiaux et al. (1987); Maw et al. (1993) and Sparks et al. (2005) (Fig. 7).

Testing the proposed revisions to the COMFA model

The following section will present the results of a reanalysis of the field data presented in Part A, based on the revisions proposed above pertaining to clothing resistance $\left(r_{c}\right)$, clothing vapour resistance $\left(r_{c v}\right)$, skin tissue resistance $\left(r_{t}\right)$, effective air velocity $\left(v_{r}\right)$, and skin temperature $\left(T_{s k}\right)$.

The field data presented in Part A were used to test the performance of the revised model (COMFA*) with the following revised equations substituted into the model:

- tissue resistance ( $r_{t}$, Eq. 2), replaces Eq. 6 of the COMFA model presented in Part A.

- relative air velocity ( $v_{r}$, Eq. 3). Relative air velocity replaced wind velocity $(V)$ in all components of the

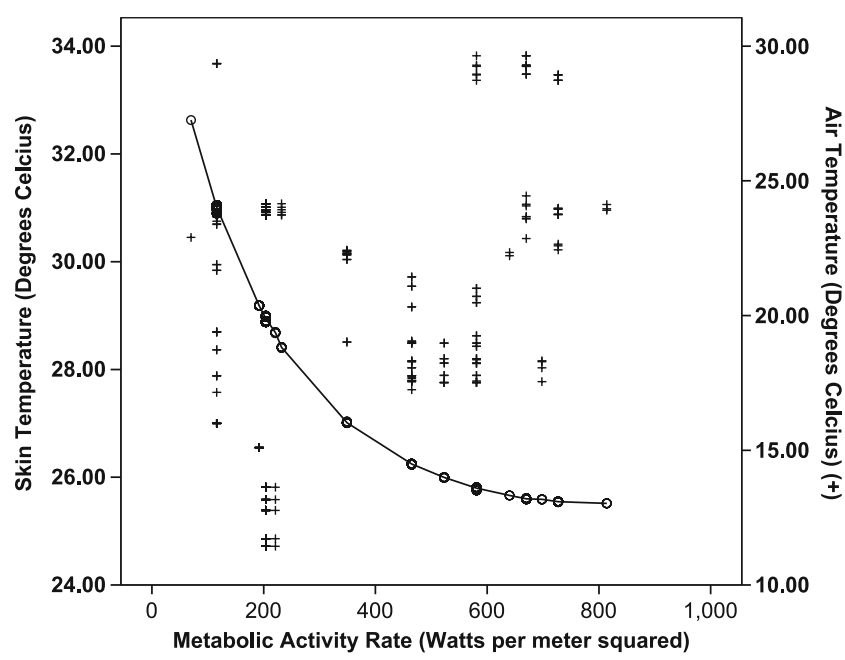

Fig. 6 Predicted skin temperature plotted at various air temperatures $(+)$, and at various metabolic activity rates $(\circ)$ for the revised COMFA model based on the field data presented in Part A 


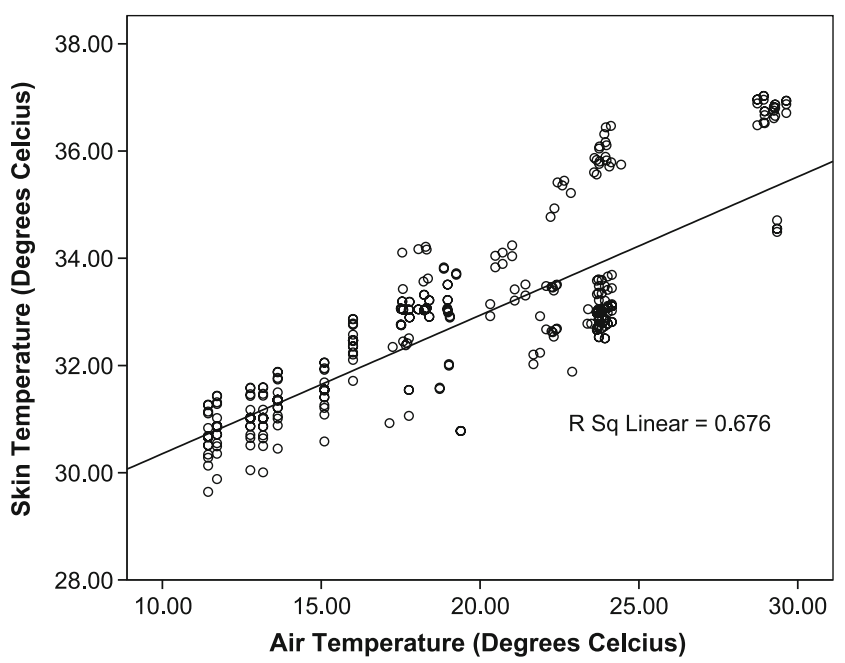

Fig. 7 Predicted skin temperature plotted at various air temperatures (using Eq. 7) for the revised COMFA model based on the field data presented in Part A, with a regression-based fit line

COMFA equations presented in Part A, with the exception of the radiation absorbed by the CRT $\left(R_{R T}\right)$.

- clothing resistance $\left(r_{c}\right.$, Eq. 5) replaces Eqs. 8 and 9 of the COMFA model presented in Part A.

- clothing vapour resistance $\left(r_{c v}\right.$, Eq. 6) and is added to the COMFA model. Static clothing insulation $\left(r_{c v o}\right)$ values were obtained from ISO9920 (2007).

- $\quad$ skin temperature $\left(T_{s k}\right)$ was calculated based on Eq. 7.

\section{Results and discussion}

Table 3 displays a comparison of the descriptive statistics for each of the model components in the original and revised assessment of the model. The mean COMFA* budget value was reduced by $44 \mathrm{~W} \mathrm{~m}^{-2}$ and the range in the budget values was reduced by $146 \mathrm{~W} \mathrm{~m}^{-2}$ in comparison to the original assessment. The COMFA* model increased the mean convective heat losses $(C)$ by $26 \mathrm{~W} \mathrm{~m}^{-2}$, and the mean longwave radiation emissions by $18 \mathrm{~W} \mathrm{~m}^{-2}$. The range in the convective heat losses was substantially reduced $\left(356 \mathrm{~W} \mathrm{~m}^{-2}\right)$ in the revised assessment. There was little change $\left(0.2 \mathrm{~W} \mathrm{~m}^{-2}\right)$ in the mean evaporative heat losses between the COMFA and COMFA* models, and no change in the predicted values for metabolic heat production $(M)$ and the radiation absorbed by the CRT $\left(R_{R T}\right)$, which are not dependent upon the proposed model changes.

Figure 8 displays the COMFA* budget values plotted for each of the ATS ratings provided by the participants. With the exception of +2 (warm), the median budget values for each ATS category were higher than the results presented in Part A. The median budget values for each ATS category were: -2 $($ cool, $n=2)=100 \mathrm{~W} \mathrm{~m}^{-2} ;-1$ (slightly cool, $\left.n=40\right)=54 \mathrm{~W}$
Table 3 Descriptive statistics for each of the components of the original model (COMFA) and the revised model (COMFA*) based on the data presented in Part A. $R_{R T}$ Radiation absorbed calculated based on CRT, $L$ longwave radiation emitted, $E$ evaporative heat losses, $C$ convective heat losses, $M$ metabolic heat production

\begin{tabular}{lllll}
\hline & Min $\left(\mathrm{W} \mathrm{m}^{-2}\right)$ & Max $\left(\mathrm{W} \mathrm{m}^{-2}\right)$ & Mean $\pm \mathrm{SD}$ & $\mathrm{MBE}^{\mathrm{a}}$ \\
\hline COMFA & & & & \\
Budget & -257 & 314 & $87 \pm 103$ & \\
$R_{R T}$ & 331 & 496 & $410 \pm 41$ & \\
$L$ & 304 & 444 & $345 \pm 27$ & \\
$E$ & 12 & 317 & $104 \pm 77$ & \\
$C$ & 32 & 581 & $155 \pm 100$ & \\
$M$ & 63 & 743 & $280 \pm 179$ & \\
COMFA* & & & & \\
Budget & -22 & 402 & $131 \pm 82$ & -44 \\
$R_{R T}$ & 331 & 496 & $410 \pm 41$ & 0 \\
$L$ & 286 & 373 & $327 \pm 23$ & 18 \\
$E$ & 11 & 299 & $103 \pm 75$ & 0.2 \\
$C$ & 40 & 233 & $129 \pm 42$ & 26 \\
$M$ & 63 & 743 & $280 \pm 179$ & 0 \\
\hline
\end{tabular}

${ }^{a}$ Mean bias error between the respective budget components presented using the original COMFA model presented in Part A and the revised COMFA* model

$\mathrm{m}^{-2} ; 0$ (neutral, $\left.n=80\right)=73 \mathrm{~W} \mathrm{~m}^{-2} ;+1$ (slightly warm, $n=156)=131 \mathrm{~W} \mathrm{~m}^{-2} ;+2($ warm, $n=90)=147 \mathrm{~W} \mathrm{~m}^{-2}$; and, $+3($ hot, $n=30)=286 \mathrm{~W} \mathrm{~m}^{-2}$. Again, as only two data points are available for the category -2 (cool), caution must be used when interpreting the results for this category.

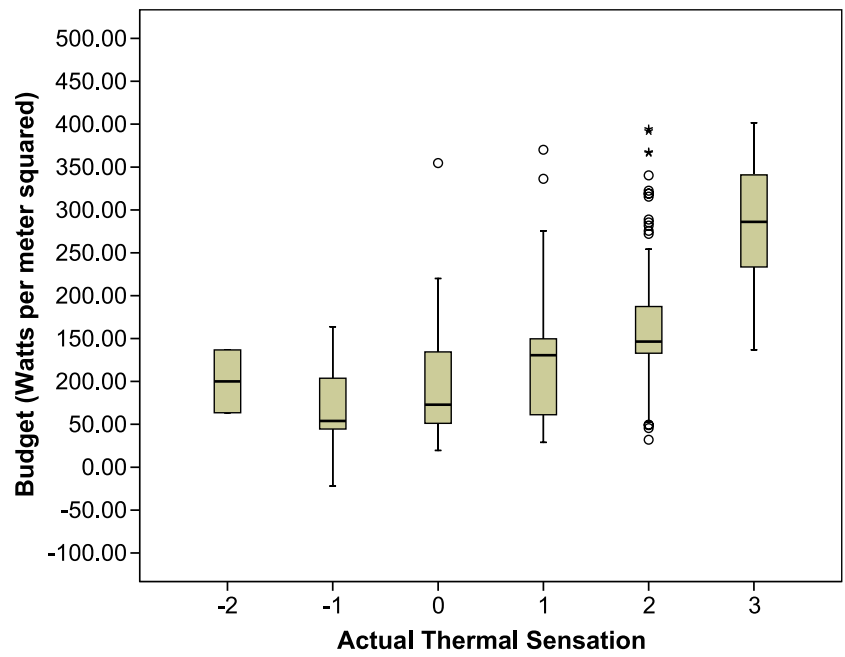

Fig. 8 Stem and leaf box plot displaying the range of the revised COMFA budget values for each of the actual thermal sensation (ATS) ratings provided by the participants during the field testing using Eq. 7 to estimate skin temperature. The length of each box is indicated by the interquartile range (IQR) between the 25th and 75th percentile. Outliers (values 1.5-3 IQRs from the end of the box) are marked by $\circ$, and $*$ denotes extreme values (values in excess of three IQRs from the end of the box) 
There was a clear overlap between the IQR for the categories -1 (slightly cool), 0 (neutral) and +1 (slightly warm). Based on these results, and an assumption that comfort is extended to include -1 (slightly cool) to +1 (slightly warm) (Fanger 1972; Thorsson et al. 2007), the following corresponding budget values for athletes performing physical activity (the categories -2 (cool) and -3 (cold) were excluded due to lack of sufficient field data) may be assumed to be:

- neutral/acceptable $(-1$ to +1$)=-20$ to $+150 \mathrm{~W} \mathrm{~m}^{-2}$

- $\quad$ warm $(+2)=151-250 \mathrm{~W} \mathrm{~m}^{-2}$

- $\operatorname{hot}(+3)=>250 \mathrm{~W} \mathrm{~m}^{-2}$.

These COMFA* budget categories vary from the original assessment of the COMFA model presented along a 5-point thermal sensation scale by Brown and Gillespie (1986), where a comfort range of neutral (0) was predicted between -50 and $+50 \mathrm{~W} \mathrm{~m}^{-2}$, warm $(+1)$ between 50 $150 \mathrm{~W} \mathrm{~m}^{-2}$, and hot $(+2) \geq 150 \mathrm{~W} \mathrm{~m}^{-2}$. In comparison, the present results suggest a much wider range of thermal acceptability, and a skewing towards the warmer end of the comfort scale. This widening of the comfort zone has been suggested by other studies and is often attributed to factors such as expectation of a more variable environment and a perceived lack of control over outdoor thermal conditions (Spagnolo and de Dear 2003; Nikolopoulou and Steemers 2003; Ahmed 2003; Nikolopoulou and Lykoudis 2006). The present study's suggestion that moderate-to-vigorous physical activity will also produce an 'activity skewing effect' in which the range of thermal neutrality is not centered on a balanced budget is similar to the seasonal skewing noted by other studies. The comfort zone occurred from -20 to $+150 \mathrm{~W} \mathrm{~m}^{-2}$, given the conditions tested in this study.

Spearman's rho rank correlation was used to assess the relationship between the ATS votes and predicted budget values. Overall, the predicted budget values and ATS votes were significantly positively correlated (correlation coefficient $=0.523, P<0.01$ ). Due to the overlap in the thermal sensation categories slightly cool $(-1)$, neutral $(0)$ and slightly warm $(+1)$, it is difficult to distinguish a clear budget range for each of these categories by calibrating them against the COMFA budget values. Therefore, a 5point ATS and PTS physical activity comfort scale was devised by collapsing the ATS categories -1(slightly warm), 0(neutral), and +1 (slightly cool) into one neutral comfort zone and defining the remaining zones as:

- $\quad$ cold $(-2)=<-151 \mathrm{~W} \mathrm{~m}^{-2}$

- $\operatorname{cool}(-1)=-150$ to $-20 \mathrm{~W} \mathrm{~m}^{-2}$

- neutral/acceptable $(0)=-20$ to $150 \mathrm{~W} \mathrm{~m}^{-2}$

- $\quad$ warm $(+1)=151$ to $250 \mathrm{~W} \mathrm{~m}^{-2}$

- hot $(+2)=>250 \mathrm{~W} \mathrm{~m}^{-2}$
It is important to note that when conducting field research, the 7-point subjective thermal sensation scale remains the most widely applied, as a 5-point thermal sensation scale is suggested to limit the participants' ability to accurately describe their thermal sensation (e.g. to be able to choose slightly warm/cool) (Spagnolo and de Dear 2003; Parsons 2003). However, due to the clear overlap in the budget ranges for the neutral and slightly warm/cool categories, the 5-point thermal sensation scale is more appropriate for practical analysis and application to planning and design.

Using these comfort category ranges, the COMFA* PTS scores and subjective ATS votes in the present study were equal $67 \%$ of the time and were significantly positively correlated (correlation coefficient $=0.415, P<0.01$ ). A similar analysis of the data presented in original assessment of the COMFA model presented in Part A reveals that the COMFA PTS and ATS votes were equal $59 \%$ of the time when comparing the results based on a 5 point scale [i.e. extending the neutral zone to include the categories -1 (slightly warm), 0 (neutral) and +1 (slightly warm); correlation coefficient $=0.463, P<0.01]$. It is noted that the improvement in the model is not revealed in the nonparametric correlation analysis, and that there is actually a slight decrease in the correlation coefficient. However, this analysis may not provide an effective measure of the association between the ATS and PTS votes along a 5-point scale, and it is important to further assess the distribution of responses for each of the comfort categories.

The distribution of the votes in each of the comfort categories is markedly improved in the COMFA* model, with a nearly equal distribution between the ATS and PTS votes in each of the categories (Fig. 9). In comparison, Fig. 10 displays the frequency distribution of PTS scores along a 5-point scale from the original assessment presented in Part A. The revisions to the model clearly improved the model's performance in predicting the distribution of the actual thermal sensation votes provided by the subjects during field testing.

Recognising that there is likely to be great interpersonal variation in thermal sensation ratings, Fanger (1972) states that it is most important to assess the portion of people who would be 'decidedly uncomfortable', which he defines as an ATS of $\leq-2$ (cool) and $\geq+2$ (warm). The portion of the subjects' ATS votes in this range was $31 \%$ over the course of the field testing period. The COMFA* model estimated a similar portion $(28 \%)$ of PTS values within this range of thermal discomfort (budget $\geq 50 \mathrm{~W} \mathrm{~m}^{-2}$ ). There were no values predicted or observed at the lowest end of the comfort scale in this study. These results suggest that the COMFA* outdoor thermal comfort model performed quite well in comparison to other models (e.g. Nikolopoulou and Steemers 2003).

In $4.5 \%$ of cases, the COMFA* model substantially under or over estimated the ATS votes, as indicated by the outlier 

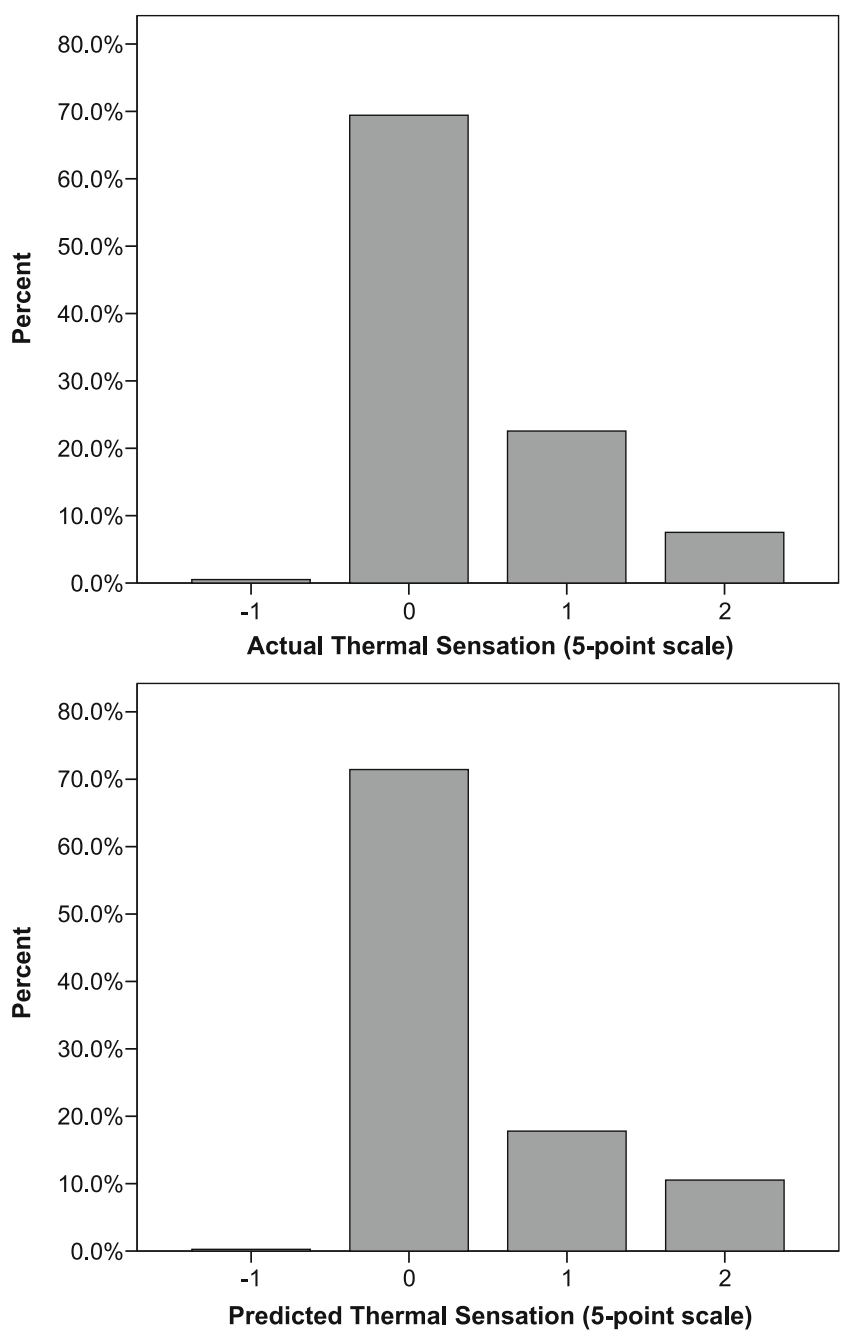

Fig. 9 Frequency distribution of the ATS and predicted thermal sensation (PTS) votes (based on the COMFA* model) along a 5-point scale [7-point scale categories $+1 /-1$ (slightly warm/cool) have been collapsed into the category 0 (neutral)]. 5-point scale categories are -2 (cold), -1 (cool), 0(neutral), +1 (warm) and +2 (hot)

and extreme values in Fig. 8. Removing these extreme and outlier values only slightly improves the correlation between the predicted budget values and ATS votes (Spearman's rho correlation coefficient $=0.531, P<0.01)$. The majority $(78 \%)$ of these outliers and extreme values occurred under warm conditions $\left(T_{a}=24-29^{\circ} \mathrm{C}, T_{r t}=27-30^{\circ} \mathrm{C}\right)$, when the subjects were running at high metabolic rates $\left(694-814 \mathrm{~W} \mathrm{~m}^{-2}\right)$, and the predicted thermal sensation budget values ranged from 281-393 $\mathrm{W} \mathrm{m}^{-2}$ (+3 or hot) (Table 4). The outliers were almost evenly distributed between male (44\%) and female $(56 \%)$ subjects (Table 5$)$. The vast majority $(83 \%)$ of the outlier and extremes occurred in the actual thermal sensation (ATS) category +2 (warm); $78 \%$ of the ATS votes underestimated the corresponding PTS values of $+3\left(\geq 250 \mathrm{~W} \mathrm{~m}^{-2}\right)$; and $90 \%$ occurred between time $=5-20 \mathrm{~min}$.

There are likely both psychological and physiological reasons associated with the discrepancy between ATS and
PTS votes associated with these outlier and extreme values. Past outdoor thermal comfort research has confirmed that subjects rarely choose the extreme $(<-2,>+2)$ ends of the thermal sensation scale (Nikolopoulou et al. 2001; Thorsson et al. 2007). In the present study, the ATS category +3(hot) was chosen $7.5 \%$ of the time during field testing. All $7.5 \%$ of the ATS $=+3$ (hot) votes where chosen by participants from time $=15-30 \mathrm{~min}$, and most $(83 \%)$ of the ATS $=+3$ (hot) responses occurred from time $=20-30 \mathrm{~min}$.

In the present study, metabolic heat production and body core temperature were based on metabolic activity rates, which were estimated by the participants' activity and speed. Physiological research has suggested that there is a rapid increase in core temperature with the onset of exercise, and that although core temperature will stabilise after approximately $20-30 \mathrm{~min}$, it will usually continue to steadily increase in small increments throughout the entire duration of exercise (Maw et al. 1993; Sparks et al. 2005; Jay et al. 2007). It is likely that core temperatures may have been over-estimated during the first $15 \mathrm{~min}$ of field testing, as the model does not account for a 'lag' in the rise in core body temperature and that there is a corresponding delay in subjective feelings of discomfort. This error was particularly evident with the high metabolic rates of the runners during the first $20 \mathrm{~min}$ of field testing on warm days.

\section{Conclusion}

The outdoor thermal environment is highly complex, and both physiological and psychological factors associated with thermal sensation are further confounded at higher rates of

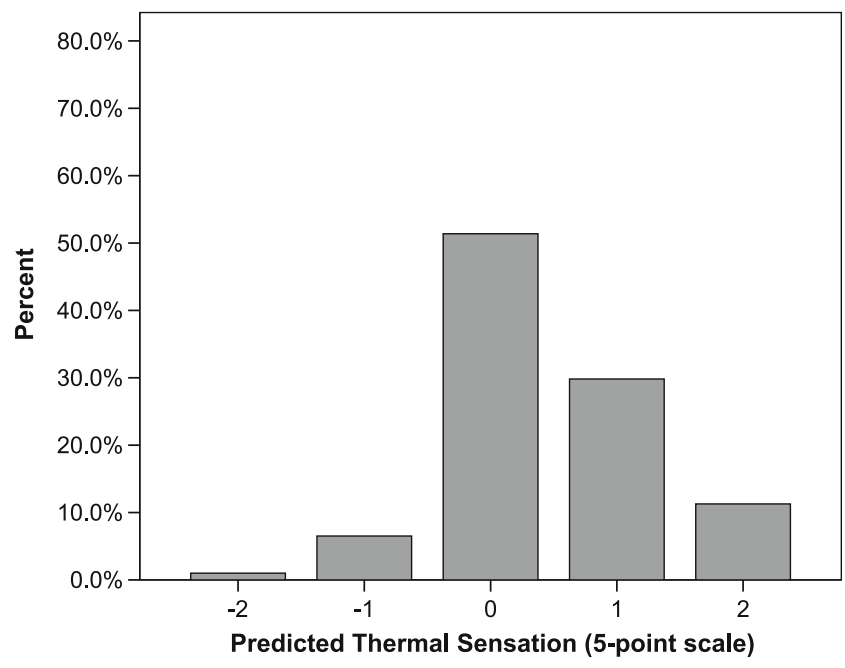

Fig. 10 Frequency distribution of PTS votes along a 5-point scale (based on the original COMFA model presented in Part A) (7-point scale categories $+1 /-1$ (slightly warm/cool) have been collapsed into the category 0 (neutral)). 5-point scale categories are -2 (cold), -1 (cool), 0 (neutral), +1 (warm) and +2 (hot) 
Table 4 Summary of the mean meteorological, participant and budget data for the outlier and extreme COMFA* budget values $(n=18)$ presented in Fig. 8. $T_{a}$ Air temperature, $T_{r t}$ CRT temperature, RH relative humidity, $v_{\mathrm{w}}$ wind speed, $v_{a}$ activity speed, $M_{a}$ metabolic rate, $r_{c o}$ static clothing resistance, $r_{c v o}, B$ budget storage

\begin{tabular}{lllllllllll}
\hline Date & $N$ & $T_{a}\left({ }^{\circ} \mathrm{C}\right)$ & $T_{r t}\left({ }^{\circ} \mathrm{C}\right)$ & $R H(\%)$ & $v_{w}\left(\mathrm{~m} \mathrm{~s}^{-1}\right)$ & $v_{a}\left(\mathrm{~m} \mathrm{~s}^{-1}\right)$ & $M_{a}\left(\mathrm{~W} \mathrm{~m}^{-2}\right)$ & $r_{c o}\left(\mathrm{~s} \mathrm{~m}^{-1}\right)$ & $r_{c v o}\left(\mathrm{~s} \mathrm{~m}^{-1}\right)$ & $B\left(\mathrm{~W} \mathrm{~m}^{-2}\right)$ \\
\hline 30 October 2006 & 4 & 12.1 & 14.7 & 41.7 & 1.8 & 1.4 & 204 & 129 & 312 & 44 \\
30 July 2007 & 7 & 23.7 & 27.7 & 52.6 & 1.7 & 3.3 & 694 & 72 & 184 \\
31 July 2007 & 5 & 29.3 & 30.3 & 48.7 & 1.9 & 3.2 & 652 & 62 & 184 & 351 \\
28 August 2007 & 2 & 24.0 & 26.9 & 55 & 3.2 & 3.9 & 814 & 78 & 184 & 393 \\
\hline
\end{tabular}

physical activity. It is of utmost importance to test and adapt outdoor thermal comfort models to the specific context to which they are intended to be applied to ensure accurate estimates of the heat and moisture exchanges between the human body and the surrounding environment. This paper has clearly identified conditions under which the COMFA outdoor thermal comfort model produced erroneous estimates of the heat and moisture exchanges between the human body and the ambient environment. Most of these errors occurred when subjects were performing at high metabolic rates $\left(>400 \mathrm{~W} \mathrm{~m}^{-2}\right)$, under relatively high wind speeds $\left(>4 \mathrm{~m} \mathrm{~s}^{-1}\right)$, and warm air temperatures $\left(>28^{\circ} \mathrm{C}\right)$. Based on recent empirical research, revisions to the clothing resistance $\left(r_{c}\right)$, clothing vapour resistance $\left(r_{c v}\right)$, skin tissue resistance $\left(r_{t}\right)$, and skin temperature $\left(T_{s k}\right)$ equations presented in Part A of this study were proposed. In addition, as the COMFA model did not consider the combined effect of wind and activity speed, a simple method for calculating effective air velocity $\left(v_{r}\right)$ was proposed. The revised equations removed the cases in which the model clearly produced physically unreasonable results when applied to users performing at moderate-vigorous rates of physical activity, thus improving the accuracy of the model for this application.

Table 5 Frequency of response by various descriptors for the outlier and extreme values $(n=18)$ presented in Fig. 8

\begin{tabular}{|c|c|c|c|}
\hline \multicolumn{2}{|c|}{ Descriptor } & Frequency (n) & Frequency (\%) \\
\hline \multicolumn{2}{|l|}{ Male } & 8 & 44.4 \\
\hline \multicolumn{2}{|c|}{ Female } & 10 & 55.6 \\
\hline \multicolumn{2}{|c|}{$\mathrm{ATS}=0$} & 1 & 5.6 \\
\hline \multicolumn{2}{|c|}{$\mathrm{ATS}=1$} & 2 & 16.7 \\
\hline \multicolumn{2}{|c|}{$\mathrm{ATS}=2$} & 15 & 83.3 \\
\hline \multicolumn{2}{|c|}{ Walking } & 4 & 22.2 \\
\hline \multicolumn{2}{|c|}{ Running } & 14 & 77.8 \\
\hline \multirow[t]{5}{*}{ Time } & $5 \min$ & 5 & 27.8 \\
\hline & $10 \mathrm{~min}$ & 4 & 22.2 \\
\hline & $15 \min$ & 3 & 16.7 \\
\hline & $20 \min$ & 4 & 22.2 \\
\hline & $25 \mathrm{~min}$ & 2 & 11.1 \\
\hline
\end{tabular}

The assessment of the COMFA* model for application on subjects performing physical activity revealed a significant positive correlation between the ATS and predicted budget values. There was a clear overlap and little discrimination between the budget ranges for the thermal sensation categories -1 (slightly cool), 0 (neutral), and +1 (slightly warm), suggesting that subjects performing physical activity have a much wider range of thermal acceptability $\left(\mathrm{B}=-20 \mathrm{~W} \mathrm{~m}^{-2}\right.$ to $\left.+150 \mathrm{~W} \mathrm{~m}^{-2}\right)$, when compared to that of sedentary users. In addition, in comparison to the original assessment of the COMFA model, the median scores for each thermal sensation category indicated that there was an activity skewing effect towards the warmer end of the comfort scale.

The COMFA model was originally developed for users performing at low metabolic rates of activity, and the comfort categories defined by Brown and Gillespie (1986) were not well-suited for application to subjects performing at higher metabolic rates. In the present study, the comfort categories were effectively adjusted based on the actual thermal sensation votes provided by the subjects during the field tests to improved the model's performance. Additional research is warranted to assess whether a similar approach could address the psychological factors related to expectancy or seasonal/location skewing effects identified in past research (Nikolopoulou and Lykoudis 2006; Spagnolo and de Dear 2003).

Recognising that there is great interpersonal variation in thermal sensation ratings, it was determined that the COMFA* model performed well under the conditions tested, by predicting the actual thermal sensation of users approximately $70 \%$ of the time. This represents an improvement in approximately $10 \%$ of the cases presented in the original assessment of the COMFA model in Part A. In addition, both the portion of subjects' ATS votes in the range of substantial thermal discomfort $[\leq-2$ (cool) and $\geq+2$ (warm)] and the portion of predicted budget values within this range were nearly equal (both totalling approximately 30\%).

The model substantially under- or over-estimated $4.5 \%$ of the cases. Although this represents only a $1 \%$ reduction in the occurrence of outlier and extreme cases presented in the 
original assessment, in the vast majority of these cases the model overestimated the actual thermal sensation votes of the runners in the early-mid portion of the testing period and these cases were heavily concentrated in the ATS category +2 (warm). This result supports the assumption that the COMFA model did not account appropriately for a lag in core temperature increase with the onset of exercise, and that there is a corresponding delay in feelings of discomfort experienced by participants, especially when they are working at high metabolic rates under warm conditions. It is also likely that some participants were simply less apt to choose the extreme end of the comfort scale.

This paper has effectively integrated current empirical research related to the heat and moisture exchange within the clothing microclimate to improve the accuracy the COMFA outdoor thermal comfort model for application on users performing moderate-vigorous physical activity. The results of the present study confirm that the COMFA* model can be used to effectively predict and quantify the thermal comfort of users performing at higher rates of metabolic activity in outdoor environments. Given the prevalence of physical inactivity, and the fact that thermal comfort is one of the major factors which influence outdoor activity, planners and designers can promote increased use, and help to ensure the well-being of users by designing recreational spaces that are thermally comfortable. The application of outdoor thermal comfort models in urban design is promising and the COMFA* thermal comfort model can be used as an effective tool that promotes a climate-conscious approach to the planning and design of outdoor spaces.

Acknowledgement Funding for this project was generously provided by the Natural Sciences and Engineering Research Council of Canada (NSERC).

\section{References}

Ahmed K (2003) Comfort in urban spaces: defining boundaries of outdoor thermal comfort for the tropical environments. Energy Build 35:103-110

Bouskill L, Havenith G, Kuklane K, Parsons K, Withey W (2002) Relationship between clothing ventilation and thermal insulation. Am Ind Hyg Assoc J 63:262-268

Brown R, Gillespie T (1986) Estimating outdoor thermal comfort using a cylindrical radiation thermometer and an energy budget model. Int J Biometeorol 30(1):43-52

Campbell G (1977) An introduction to environmental biophysics. Springer, New York

Campbell G, Norman J (1998) An introduction to environmental biophysics, 2nd edn. Springer, New York

Fanger P (1972) Thermal comfort. McGraw-Hill Book Company, New York

Fukazawa T, Lee G, Matsuoka T, Kano K, Tochihara Y (2004) Heat and water vapour transfer of protective clothing systems in a cold environment, measured with a newly developed sweating manikin. Eur J Appl Physiol 92:645-648

Ghali K, Ghaddar N, Jones B (2002) Modeling of heat and moisture transport by periodic ventilation of thin cotton fibrous media. Int J Heat Mass Transfer 45:3703-3714

Havenith G, Nilsson H (2004) Correction of clothing insulation for movement and wind effects, a meta-analysis. Eur J Appl Physiol 34:581-591

Havenith G, Heus R, Lotens W (1990a) Clothing ventilation, vapour resistance and permeability index: changes due to posture, movement and wind. Ergonomics 33:989-1005

Havenith G, Heus R, Lotens W (1990b) Resultant clothing insulation: a function of body movement, posture, wind, clothing fit and ensemble thickness. Ergonomics 33:67-84

Havenith G, Holmer I, Den Hartog E, Parsons K (1999) Clothing evaporative heat resistance - a proposal for improved representation in standards and models. Ann Occup Hyg 43:339-346

Havenith G, Holmer I, Parsons K (2002) Personal factors in thermal comfort assessment: clothing properties and metabolic heat production. Energy Build 34:581-591

Holmer I, Nilsson H, Havenith G, Parsons K (1999) Clothing convective heat exchange-proposal for improved prediction in standards and models. Ann Occup Hyg 43:329-337

ISO9920 (2007) Ergonomics of the thermal environment - estimation of the thermal insulation and the water vapour resistance of a clothing ensemble. Technical Report ISO9920, International Standards Organization

Jay O, Reardon F, Webb P, DuCharme M, Ramsay T, Nettlefold L, Kenny G (2007) Estimating changes in mean body temperature for humans during exercise using core and skin temperatures is inaccurate even with a correction factor. J Appl Physiol 103:443-451

Kerslake D (1972) The stress of hot environments. Cambridge University Press, London

Kreith F, Black W (1980) Basic heat transfer. Harper and Row, New York

Lotens W, Havenith G (1991) Calculation of clothing insulation and vapour resistance. Ergonomics 34:233-254

Lotens W, Wammes L (1993) Vapour transfer in two-layer clothing due to diffusion and ventilation. Ergonomics 36:1223-1240

Mairiaux P, Malchaire J, Candas V (1987) Prediction of mean skin temperature in warm environments. Eur J Appl Physiol 56:686-692

Maw G, Boutcher S, Taylor N (1993) Ratings of perceived exertion and affect in hot and cool environments. Eur J Appl Physiol 67:174-179

McCullough E, Jones B, Tamura T (1989) A database for determining the evaporative resistance of clothing. ASHRAE Trans 95:316-328

Monteith J, Unsworth M (1990) Principles of environmental physics, 2nd edn. Butterworth-Heinemann, Boston, Mass

Nielsen R, Olesen B, Fanger P (1985) Effect of physical activity and air velocity on the thermal insulation of clothing. Ergonomics 28:1617-1631

Nikolopoulou M, Lykoudis S (2006) Thermal comfort in outdoor urban spaces: analysis across different European countries. Build Environ 41:1455-1470

Nikolopoulou M, Steemers K (2003) Thermal comfort and psychological adaptation as a guide for designing urban spaces. Energy Build 35:95-101

Nikolopoulou M, Baker N, Steemers K (2001) Thermal comfort in outdoor urban spaces: Understanding the human parameter. Sol Energy 70(3):227-235

Oke T (1987) Boundary layer climates, 2nd edn. Routledge Taylor and Francis Group, New York

Parsons K (2003) Human thermal environments, 2nd edn. Taylor and Francis, New York

Parsons K, Havenith G, Holmer I, Nilsson H, Malchaire J (1999) The effects of wind and human movement on the heat and vapour transfer properties of clothing. Ann Occup Hyg 43:347-352 
Spagnolo J, de Dear R (2003) A field study of thermal comfort in outdoor and semi-outdoor environments in subtropical Sydney Australia. Build Environ 38:721-738

Sparks S, Cable N, Doran D, Maclaren D (2005) The influence of environmental temperature on duathlon performance. Ergonomics 48:1558-1567
Thorsson S, Lindqvist M, Lindqvist S (2004) Thermal bioclimatic conditions and patterns of behaviour in an urban park in Goteborg, Sweden. Int J Biometeorol 48:149-156

Thorsson S, Honjo T, Lindberg F, Eliasson I, Lim E (2007) Thermal comfort and outdoor activity in Japanese urban public places. Environ Behav 39:660-684 